Pamiętnik Literacki 2019, 1, s. 17-41

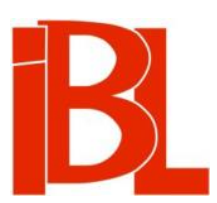

\title{
Wątki religijne w twórczości Brunona Schulza. Stan badań i perspektywy badawcze
}

Sotirios Karageorgos 
Pamiętnik Literacki CX, 2019, z. 1, PL ISSN 0031-0514

DOI: $10.18318 / \mathrm{pl} .2019 .1 .2$

SOTIRIOS KARAGEORGOS Uniwersytet Warszawski

\title{
WĄTKI RELIGIJNE W TWÓRCZOŚCI BRUNONA SCHULZA STAN BADAŃ I PERSPEKTYWY BADAWCZE
}

\begin{abstract}
Stan badań
Jerzy Jarzębski w swojej książce o Schulzu pisze:

Schulz nie był wyznawcą żadnej określonej religii: wystąpił z gminy żydowskiej, nie zdecydował się nawet w obliczu ruiny planów małżeńskich - na przyjęcie chrześcijaństwa, świat był jednak dla niego metafizycznym ogrodem tajemnic, a rzeczywistość objawiała na każdym kroku swoją duchową naturę, był więc zapewne „wierzącym bez religii” - przypadek dość częsty w XX w., który „uśmiercił Boga”, ale nie był w stanie unieważnić dramatycznych pytań o istotę i sens egzystencji ${ }^{1}$.

Artur Jocz z kolei w artykule Literatura a religia. O potrzebie religioznawczej refleksji $w$ obrębie literaturoznawstwa, komentując zdanie Jerzego Ficowskiego o Schulzu, dodaje:

pogłębione studia nad twórczością Brunona Schulza [...] wymagają także religioznawczego wsparcia. [...] do naukowego ogarnięcia fenomenu wykreowanej przez Schulza rzeczywistości potrzebna jest również wiedza religioznawcza. Nature literackiego świata nauczyciela rysunku z Drohobycza lepiej pomoga zinterpretować „badania parareligioznawcze, psychoetnologiczne niż klasyczne metody literaturoznawstwa"2.
\end{abstract}

Tak zarysowana perspektywa studiów nad wątkami religijnymi w dziele Schulza ma wiele aspektów.

\section{Gnoza i herezja (Arkadiusz Kalin)}

W twórczości literackiej szczególnie widoczne są nawiązania Schulza do gnostycyzmu. Badacze wielokrotnie podkreślali znaczenie wątków gnostyckich w utworach pisarza, np. Jocz w wymienionym artykule. Autor rozwija swoją analizę również w innej rozprawie: Bruno Schulz, czyli o gnostycznej pokusie literatury.

Dla niniejszej pracy jednak bardziej istotne jest zdanie Arkadiusza Kalina,

1 J. J arzęb ski, Schulz. Wrocław 1999, s. 153.

2 A. J o c z, Literatura a religia. O potrzebie religioznawczej refleksji $w$ obrębie literaturoznawstwa. „Humaniora. Czasopismo Internetowe” 2013, nr 3, s. 46. Na stronie: http://humaniora.amu.edu. pl/sites/default/files/humaniora/Humaniora\%20nr\%203/Hum_nr_3_Jocz_M.pdf (data dostępu: 8 VII 2018). 
wyrażone w studium Księga heretycka - Schulzowski model kultury literackiej ${ }^{3}$. W tekście tym badacz zwraca uwagę m.in. na heretyckość gnostycyzmu. Podkreśla, że zalicza się on do największych herezji w dziejach kultury judeochrześcijańskiej. Ojciec „"herezjarcha" [...] opętany [jest] "kacerską doktryną" [...]"4. Cały jego traktat (Traktat o manekinach) nasycony został motywami typowymi dla gnozy: Demiurg, duch, materia, kreacja, problem zła i cierpienia, itp. Opowiadanie ma charakter traktatu teologiczno-naukowego i sam podtytuł - albo Wtóra Księga Rodzaju wskazuje na tę księgę Starego Testamentu, która najbardziej interesowała gnostyków. Według badacza do tradycji gnostyckiej Schulz sięga raczej jako do pewnego rezerwuaru wątków i symboli bez wyszczególnienia odwołań do konkretnych szkół gnozy. Ze względu na jej wydźwięk heretycki jest ona atrakcyjna dla pisarza. W opowiadaniu Nawiedzenie przedstawiony zostaje spór Jakuba (ojca) z Bogiem, nawiązujący do Biblii w apokryficznej wersji, ponieważ, jak podkreśla Kalin, walka ta ma zmieniony finał: ojciec „zanika, więdnie w oczach” w następstwie kłótni z Demiurgiem $^{5}$, zamiast - jak czytamy w Księdze Rodzaju - zapewnić sobie opiekę, błogosławieństwo i dobrobyt. Demiurg odpowiada za zło na świecie, zło jednak jest raczej wynikiem skażenia procesu kreacji niż istnienia transcendentalnej zasady szatana. Gnoza, nie rezygnując z dualizmu, nie konstruuje opozycji: „bóg dobra” - „bóg zła”. Podobnie w opowiadaniach Schulza nie ma uzasadnienia dla zła jako transcendentalnego elementu ingerencji. Zło pojawia się jako skutek skażenia, deformacji, pomyłki. W finale pierwszej części Traktatu o manekinach widzimy, że Adela interweniuje, przerywając ojcu i kusząc go wypiętym pantofelkiem, który „błyszczał jak języczek węża"6. Badacz tłumaczy tę scenę aluzją do kuszenia Adama w raju, aluzja do grzechu pierworodnego. Twórczość rodzi się ze zdrady ducha „uwodzonego" przez materię. Ojciec w końcu - tak jak gnostycy - oddziela Demiurga, Stwórcę od materii. Materia jest czymś pierwotniejszym, niezależnym od Demiurga.

Wątek gnostycyzmu powraca również w Sanatorium Pod Klepsydra. Tam, w opowiadaniu Wiosna, pojawia się Franciszek Józef, potężny i smutny Demiurg, który obejmuje świat i ogranicza go ze wszystkich stron. Piszą o tym obaj badacze, Jocz i Kalin. Istotne jednak wydają się słowa Kalina o tym, że Schulz nie jest wyznawcą gnozy - tylko „raczej jej "użytkownikiem"”?

\section{Kabała i mesjanizm (Władysław Panas)}

Drugi, gruntownie zbadany, wątek religijny w dziele Schulza to Kabała. Władysław Panas w Księdze blasku interpretuje dorobek artystyczny pisarza według jej odmiany luriańskiej ${ }^{8}$. Kabalistyczne stworzenie świata („,imcum”) badacz rozpoznaje wyraźniej w opowiadaniu Noc wielkiego sezonu oraz w artykule krytycznym Schul-

A. Ka li n, Księga heretycka-Schulzowski model kultury literackiej. W zb.: W ułamkach zwierciadła... Bruno Schulz w 110 rocznicę urodzin i 60 rocznicę śmierci. Red. M. Ki tow s k a - Ły si a k, W. Pa n a s. Lublin 2003.

Ibidem, s. 299.

B. Schulz, Nawiedzenie. W: Proza. Przedm. A. Sand a uer. Wyd. 2. Kraków 1973, s. 49.

B. Schulz, Traktat o manekinach, albo Wtóra Księga Rodzaju. W: jw., s. 65.

Kalin, op. cit., s. 318.

$8 \quad$ W. Pa n a s, Księga blasku. Traktat o kabale w prozie Brunona Schulza. Lublin 1997. 
za Ega Van Haardt. Upadek stworzenia („szwirat ha kelim”) został przedstawiony w Ulicy Krokodyli, a zbawienie świata („tikkum”) bardziej widoczne jest według Panasa w dwóch pierwszych opowiadaniach Sanatorium Pod Klepsydra, czyli Księdze i Genialnej epoce. Zbawienie świata, jego zdaniem, stanowi istotę całej twórczości Schulza.

Zanim Panas wydał Księgę blasku, napisał artykuł Mesjasz rośnie pomału... O pewnym watku kabalistycznym $w$ prozie Brunona Schulza ${ }^{9}$. W szkicu tym badacz zajmuje się ściślej kontrowersyjnym tematem Mesjasza w dziele Schulza i czyni w związku z tym interesujące uwagi. Najpierw podkreśla fakt, że Mesjasz to niezrealizowana powieść, która miała być opus vitae pisarza. Druga opowieść Sanatorium Pod Klepsydra, czyli Genialna epoka, jak utrzymywał sam autor, to fragment Mesjasza. Panas słusznie dodaje, że pierwsza część Sanatorium Pod Klepsydra, czyli Księga, oczywiście i jednoznacznie wiąże się z Genialna epoką. Badacz, komentując twierdzenie Schulza, iż Mesjasz będzie dalszym ciagiem Sklepów cynamonowych, wnioskuje, że utwór nawiązywał do wcześniejszego dzieła, ale także to dzieło musiało zawierać jakieś „mesjańskie antycypacje”, a więc Mesjasz w pewien sposób istnieje już w prozie Schulza. Tytuł Mesjasz to nie zwykły termin sakralny, lecz sacrum maksymalnie zintensyfikowane. Nadzwyczajny fragment przedstawiajacy przybycie Mesjasza w Genialnej epoce - według badacza - należy do najpiękniejszych w całej prozie Schulza:

Jeden jedyny raz w całej znanej twórczości Schulza mówi się bezpośrednio, eksplicytnie, wprost o Mesjaszu, o osobie Mesjasza. [...] Historia przyjścia Mesjasza, czyli Odkupienia, została opowiedziana w pięciu zdaniach! Bo to jest kompletna opowieść, to jest cały, choć lapidarny, tekst. Księga w pięciu zdaniach $^{10}$.

Kolejna znaczaca uwaga Panasa dotyczy tego, że w rysunkowych wersjach Przybycia Mesjasza Schulza nie pojawia się osoba Zbawiciela. Powtórne dzieciństwo pisarza, „Genialna epoka” i „czasy Mesjasza” są w istocie tożsame. Droga prowadząca ku końcowi wszystkich rzeczy stanowi zarazem drogę ku ich poczatkowi. Wątek mesjański to główna idea Schulzowskiej refleksji o twórczości i jednocześnie zasadnicza strategia odnosząca się do praktyki artystycznej. Wszystkie „momenty” mesjańskie w prozie Schulza, szczególnie zaś w Księdze i w Genialnej epoce, pojawiają się bezpośrednio w związku z działaniami artystycznymi bohatera. Na pytanie, czy „Genialna epoka” zdarzyła się, czy nie, autor Sklepów cynamonowych odpowiada twierdząco i przecząco równocześnie:

Bo są rzeczy, które się całkiem, do końca, nie mogą zdarzyć. Są za wielkie, ażeby się zmieścić w zdarzeniu, i za wspaniałe. Próbują one tylko się zdarzyć, próbują gruntu rzeczywistości, czy je uniesie. I wnet się cofają, bojąc się utracić swą integralność w ułomności realizacji ${ }^{11}$.

Po wydrukowaniu Księgi blasku Panas napisał artykuł Żeński Mesjasz, czyli $o$ „Wiośnie” Brunona Schulza ${ }^{12}$. W pracy tej badacz formułuje interesujące uwagi

W. P a n a s, Mesjasz rośnie pomału... O pewnym watku kabalistycznym w prozie Brunona Schulza. W zb.: Bruno Schulz in memoriam 1892-1942. Red. M. Kit ow s k a - Ły s i k. Lublin 1992.

Ibidem, s. 117.

B. Schulz, Ksiega. W: Proza, s. 132.

W. P a n a s, Żeński Mesjasz, czyli o „Wiośnie” Brunona Schulza. W zb.: W ułamkach zwierciadła... 
dotyczące motywu Mesjasza w Wiośnie. Zanim Schulz wydał Sanatorium Pod Klepsydra, zbiór opowiadań, zawierający ostateczną wersję Wiosny, rok wcześniej opublikował w miesięczniku „Kamena” (1935, nr 10) fragment tego opowiadania, którego nie ma w całości w edycji z 1936 roku. Tym passusem pisarz - jak wspominał redaktorowi „Kameny” 16 III 1935 - był wyraźnie usatysfakcjonowany. $Z$ ostatecznej wersji Wiosny jednak, o czym nadmieniał w liście do Tadeusza Brezy, nie był zadowolony ${ }^{13}$. Schulz usuną fragment wydany w „Kamenie” z edycji z 1936 roku prawdopodobnie dlatego, że - jak twierdził Jerzy Ficowski - nie przystawał do całości utworu ${ }^{14}$. Widzimy w nim opis żydowskiego święta Paschy.

Kolejna uwaga Panasa dotyczy ilustracji załączonych przez Schulza do tomu Sanatorium Pod Klepsydrą. Wśród nich znajdowały się też i takie, które nie odnoszą się bezpośrednio do żadnego tekstu. $Z$ tego powodu Ficowski postanowił je usunąć $\mathrm{z}$ albumu $\mathrm{z}$ ilustracjami autorskimi Schulza ${ }^{15}$. Pokazują one nagie kobiety i mężczyzn siedzących przy stołach bądź nagie kobiety w powozach. W opowiadaniu Wiosna główny bohater, Józef, ożywia figury woskowe wchodzące w skład wędrownego panoptikum, żeby posiadać armię, która będzie broniła sukcesyjnych praw Bianki. Figurę jej ojca, arcyksięcia Maksymiliana, Józef budzi, wypowiadając żarliwym szeptem do jego ucha imię Bianki i wymawiając powoli i dobitnie imię wroga - Franciszka Józefa Habsburga. Figury woskowe to monarchiści i antymonarchiści, rewolucjoniści i kontrrewolucjoniści, anarchista włoski Luigi Luccheni, zabójca cesarzowej Elżbiety, czyli morderca Habsburgów. Widzimy tutaj w jednym zgodnym stadle jagnię i wilka, antylopę i lwa, czyli apokaliptyczną scenę wiecznego królestwa mesjańskiego. Pod koniec artykułu badacz dodaje, że Wiosna narodziła się podczas urlopu, który Schulz dostał na pisanie powieści Mesjasz. Według Panasa usunięty passus zamieszczony w „Kamenie”, miał stanowić część planowanej powieści Mesjasz, gdzie Zbawca byłby mężczyzną. Wiosna powstała w jej zastępstwie i dlatego postać Bianki postrzega narrator jako Mesjasza, żeńskiego Mesjasza.

\section{Bałwochwalstwo i idolatria (Kris Van Heuckelom)}

Trzeci motyw religijny, najbardziej widoczny w pozaliterackiej twórczości Schulza, to bałwochwalstwo. Jan Gondowicz m.in. podkreśla religijne, a raczej religioznawcze źródła Xięgi bałwochwalczej. Według badacza Schulzowska sakralizacja erotyzmu może być traktowana jako próba wskrzeszenia starożytnego kultu bogini Bliskiego Wschodu - Astarte. O tym świadczy „orgiastyczny, lecz nie dionizyjski charakter odmalowanych adoracji” ${ }^{16}$. Rys lunarny, bestiarium i rekwizytoria, inicjacyjny styl ofiarnictwa - to wszystko jest swojego rodzaju odniesieniem do kananejskiej prostytucji świątynnej. Mamy tutaj do czynienia $z$ idolatrią w ścisłym znaczeniu tego słowa ${ }^{17}$.

B. Schulz, list do T. Brezy, z 11 V 1936. W: Dzieła zebrane. T. 5: Ksiega listów. Zebrał, przygotował do druku J. Fi c ow ski. Uzupełnił S. D a n e cki. Gdańsk 2016, s. 57.

Pan a s, Zeński Mesjasz [...], s. 36.

Ibidem.

J. G o n d ow ic z, Trans-Autentik. Nie-czyste formy Brunona Schulza. Warszawa 2014, s. 90.

Ibidem. 
Belgijski badacz Kris Van Heuckelom w artykule Artistic Crossover in Polish Modernism. The Case of Bruno Schulz's „Xiega Bałwochwalcza” (,The Idolatrous Booke") czyni bardzo interesujace uwagi dotyczace Schulzowskiego bałwochwalstwa, podkreśla m.in. relację słowo-obraz ${ }^{18}$. Do pewnego stopnia cykl grafik pisarza przedstawia podejmowany przez niego akt kreacyjny. Xięga bałwochwalcza - jako dzieło w trakcie tworzenia - jest ukazana na rycinie 7: Undula u artystów. Widzimy tu żeńskiego idola Undulę patrzącą na rysunek, otaczają ją artyści męscy, przeważnie rzeźbiarze i malarze. Kartkami leżącymi u jej stóp mogą być szkice lub skończone ryciny, które potencjalnie będą składać się na Xięgę bałwochwalcza. W ostatniej rycinie noszącej ten sam tytuł, co cały cykl, idol otrzymuje zwieńczone dzieło. Archaiczne „X” w słowie „Xięga” przypomina bardzo ważną książkę religijną - tekst sakralny. Termin „bałwochwalstwo” (gr. eidolo-latreia), czyli ‘adoracja fałszywego bóstwa', odnosi się do relacji wyraźnie ukierunkowanej na wzrok. Obie strony werbalno-wizualnej opozycji, księga i idol, przedstawiane są razem w różnych konfiguracjach. Drugie przykazanie Boże brzmi:

Nie będziesz miał cudzych bogów obok Mnie! Nie będziesz czynił żadnej rzeźby ani żadnego obrazu tego, co jest na niebie wysoko, ani tego, co jest na ziemi nisko, ani tego, co jest w wodach pod ziemią! Nie będziesz oddawał im pokłonu i nie będziesz im służył, ponieważ Ja Pan, twój Bóg, jestem Bogiem zazdrosnym, który karze występek ojców na synach do trzeciego i czwartego pokolenia względem tych, którzy Mnie nienawidzą ${ }^{19}$

Koncepcja idolatrii opisana w biblijnym przykazaniu jest złożona $z$ dwóch części. Pierwsza część sugeruje czynność tworzenia podejmowana przez bałwochwalcę. Druga - podporządkowanie i uległość. Schulz wykonuje obie czynności. Stosując specyficzną technikę cliché verre, artysta tworzył odbicie, czyli idola (gr. eidolon) w sposób dosłowny. Podporządkowanie Schulza idolowi jest najbardziej widoczne na rycinie Dedykacja. Na kolejnych grafikach łatwo zidentyfikować Schulza w tłumie męskich bałwochwalców składających hołd żeńskiemu idolowi. Starotestamentowy zakaz sporządzania obrazów wyraża zasadniczą przewagę formy werbalnej nad wizualną. Bóg chce pozostać w ukryciu. Jego ulubionym środkiem przekazu jest słowo, a idol koncentruje się na komunikacji wzrokowej. Ta wizualność przynależy do zmysłowości i odnosi się do niej, formy werbalne nawiązują natomiast do rozumu i duchowości. Najistotniejszy element dodany przez Schulza do opozycji między słowocentrycznym ikonoklazmem a wzrokocentryczną idolatrią to płeć. Księgę, będąca środkiem wypowiedzi werbalnej, przedstawił artysta jako typowy atrybut męski, podczas gdy idol ma wyraźnie kształty kobiece.

W całym cyklu rycin można dostrzec przejście od początkowej koncentracji na kulturze do późniejszego skupienia się na kwestiach natury obejmujących relacje między płciami. Przykazanie dotyczące bałwochwalstwa zostało złamane przez pozornych reprezentantów elity intelektualnej: dostojników religijnych, artystów,

K. V a n He u ckelo m, Artistic Crossover in Polish Modernism. The Case of Bruno Schulz's „Xiega Bałwochwalcza” (,The Idolatrous Booke”). „Immage 〈\&〉 Narrative. Online Magazine of the Visual Narrative" 2016, z. 15. Na stronie: http://www.imageandnarrative.be/inarchive/iconoclasm/ heuckelom.htm (data dostępu: 8 VII 2018).

19 Księga Wyjścia (20, 3-5). W: Pismo Święte Starego i Nowego Testamentu w przekładzie z języków oryginalnych. Oprac. Zespół Biblistów Polskich [...]. Biblia Tysiaclecia. Wyd. 4. Poznań 1996. 
starych, mądrych Żydów. Dokonuje się ostateczna ofiara - podporządkowanie księgi sferze wizualnej. Zsekularyzowana wersja tego podporządkowania może pozornie odnosić się do obiektywnego i naturalnego rozróżnienia między literaturą a malarstwem. Sztuka Schulza przekracza granice. Księga łamie ekskluzywny związek (ślub) ze słowem i popełnia cudzołóstwo z idolem. „Xięga bałwochwalcza” staje się więc księgą cudzołóstwa. Połączenie sfery werbalnej i wizualnej w sposób wyrazisty przedstawił autor w obu wersjach ryciny zwieńczającej Xięgę bałwochwalcza, gdzie księga i idol jednoczą się. Cykl Schulza nie dotyczy dominacji seksualnej, tylko dominacji jako takiej. Sfera transcendencji ustępuje tu sferze świata. W Xiędze bałwochwalczej wszakże zawiera się idea narracji. Z jednej strony, „Xięga” podporządkowuje się reprodukcji obrazowej, $\mathrm{z}$ drugiej - obrazy dostosowuja się do narracyjnego biegu książki. Artyście wolno przekraczać granice.

\section{Adoracja i dionizyjskość (Włodzimierz Bolecki)}

W artykule Witkacy -Schulz, Schulz-Witkacy. Wariacje interpretacyjne Włodzimierz Bolecki, komentując zdanie Witkacego o dziele Schulza, twierdzi, że „,sadyzm kobiecy połączony z męskim masochizmem", który Witkacy pierwszy uznał za specjalność Schulza, był przede wszystkim specjalnością samego Witkacego [...]", oraz że: „"masochizm " jako klucz do Schulzowskiej wyobraźni niewiele [...] wyjaśnia, a raczej gruntownie zaciemnia i deformuje interpretację relacji między kobietami a mężczyznami w twórczości Brunona Schulza"20.

Bolecki podkreśla także, iż niemal na wszystkich grafikach autora Xięgi bałwochwalczej kobiety znajdują się na pierwszym planie, w centrum, natomiast mężczyźni na drugim, na peryferiach. Gdy kobieta na owych grafikach jest ciałem, meżzzyzna wzrokiem, i w tych relacjach zawsze zostaje zachowany dystans. Według badacza bardzo istotny jest dla Schulza motyw spotkania. Wiąże się on z cała gamą wyrażanych odczuć: od zainteresowania, przez szacunek, do podziwu i hołdu. Hołd składany kobietom na grafikach wydaje się figura graniczną: między gestem szacunku a adoracją bałwochwalczą. W tych relacjach nie ma ani strachu, ani poniżenia, z gestów zaś przebija delikatna stylizacja religijna. To niewatpliwie świat sacrum. Komentując określenie „prowokacyjnie bluźnierczy charakter”, Krystyny Kulig-Janarek na temat Xięgi bałwochwalczej Schulza ${ }^{21}$, Bolecki twierdzi, że pisarz od bluźnierstwa i prowokacji był jak najdalej. Stykamy się tu $z$ innego rodzaju sacrum - z sakralizacją akcji, postaci i relacji między nimi. Obiektem adoracji na rysunkach i grafikach Schulza bywają także kobiety ubrane i wydaje się typowe to, że nie dają się one pochwycić spojrzeniom mężczyzn. Kobieta jest dla nich przede wszystkim nieosiagalna. Granica kobiecego regnum pozostaje nieprzekroczona.

Szczególne zainteresowanie może budzić centralna postać kobieca cyklu Xięga bałwochwalcza, która artysta nazwał Undulą. Mogła być ona traktowana jako bliźniacza siostra uosobienia zwycięskiej kobiecości prozy Schulza - Adeli. Według Ficowskiego imię Undula kojarzy z Undyną ('rusałką), z undą - 'falą', 'strumieniem', 1994, z. 1, s. 83, 84.

21 K. Kulig-J a na re k, Schulzowska mitologia. „Kresy” 1993, nr 14, s. 42. 
'wirem', 'niepokojem'. Bolecki wspomina, że Ondyna (Undyna) to tytuł opowieści niemieckiego pisarza Friedricha de la Motte Fouqué, która ukazała się w 1811 roku. Natychmiast zdobyła ona ogromną popularność i w następnym roku na jej podstawie skomponowano operę. Historię o Undynie chwalili Johann Wolfgang Goethe, Walter Scott i Richard Wagner, a w roku 1913 została ona przetłumaczona na język polski. Ondyna była nimfa, rusałka, należała do świata żywiołów. Wizję tę zaczerpnął Fouqué $z$ księgi słynnego alchemika Paracelsusa. Istoty podobne do Undyny nie posiadaja duszy indywidualnej, mają natomiast duszę zbiorową ${ }^{22}$, Undula Schulza:

zdaje się być tyleż imieniem własnym, co imieniem zbiorowym, [...] każdazkobiet [...] jest Kobietą w ogóle. [...] należy do innego, tajemniczego, nieuchwytnego i stale zmiennego świata żywiołów ${ }^{23}$.

W kolejnym swoim artykule zatytułowanym Principium individuationis. Motywy Nietzscheańskie $w$ twórczości Brunona Schulza Bolecki twierdzi, że dzieła Schulza bardzo dużo zawdzięczają filozofii sztuki Friedricha Nietzschego ${ }^{24}$. W szkicu krytycznym Zofia Nałkowska na tle swojej nowej powieści Schulz wyraża się z entuzjazmem o Nietzscheańskiej filozofii kultury, czyli dionizyjskości ${ }^{25}$. W Exposé o „Sklepach cynamonowych” Brunona Schulza czytamy, iż Schulz podobnie jak Nietzsche twierdzi, że „swoją kreację, swe fantazjowanie i snucie wywiódł z pogańskiego pojmowania życia [...]"26. Principium individuationis stanowi w koncepcji Nietzschego wyznacznik sztuki apollińskiej, która podporządkowana jest intelektowi oraz moralności. Sztuka apollińska to kłamstwo i więzienie - unicestwienie zasady principium individuationis miało więc dla Nietzscheańskiej koncepcji kultury wyzwalajacy charakter. Apollińskość i dionizyjskość są nazwami dwóch uniwersalnych i biegunowo przeciwnych koncepcji sztuki. Zdaniem Boleckiego, oba porządki istnieją w filozofii sztuki Schulza, jakkolwiek zdecydowanie wyraźniejszy okazuje się ten drugi.

Sztuka dionizyjska łamie granice, wyzwala świat, odradza go, przełamuje granice między człowiekiem i światem, kulturą i naturą. Ze zjednoczenia z nią płynie upojenie, rozkosz, ekstaza, będące wyrazem radości $z$ uwolnienia od pozoru i złudzenia tworzonego przez sztukę apollińską. Identyczny motyw odnajdujemy w prozie i esejach Schulza ${ }^{27}$.

„Dionizos [...] doświadcza na sobie "cierpień indywiduacji“ [...], został przez Tytanów rozerwany na kawałki [...]"28. Ta idea należy do centralnych motywów w filozofii sztuki Schulza. Dawna jedność słowa rozpadła się na izolowane fragmen-

Zob. na temat ondyn K. C z e c z o t, Ofelizm. Romantyczne zawłaszczenia, feministyczne interwencje. Warszawa 2016.

B olecki, op. cit., s. 89.

W. B ol e c ki, Principium individuationis. Motywy Nietzscheańskie w twórczości Brunona Schulza. W zb.: W ułamkach zwierciadła...

B. S c hulz, Zofia Natkowska na tle swej nowej powieści. „Skamander” 1939, 108/110. Przedruk w: Proza, s. 374.

B. Schulz, Exposé o „Sklepach cynamonowych” Brunona Schulza (1937). W: Szkice krytyczne. Oprac., posł. M. Kitowska-Łysiak. Lublin 2000, s. 5 (przeł. J. Fic ow ski).

B ole c ki, Principium individuationis, s. 332.

Ibidem. 
ty. Celem drohobyckiego pisarza jest odzyskanie utraconej jedności poprzez mityzację. Żeby dotrzeć do pierwotności, do mitu, do sensu, trzeba najpierw odrzucić pozór, jaki wytwarzaja języki współczesnej cywilizacji. To Schulzowska wersja krytyki kultury apollińskiej.

\section{Trzy kobiece hierofanie (Marcin Całbecki)}

Marcin Całbecki w artykule Drohobycki matriarchat. Antropologiczne watki „Sklepów cynamonowych" Brunona Schulza analizuje prozę twórcy za pomocą teorii matriarchatu Johanna Jakoba Bachofena ${ }^{29}$. Schulz nadmienił w liście do Stanisława Ignacego Witkiewicza, że w Sklepach cynamonowych starał się „odnaleźć własną, prywatną mitologię, własne "historie", własny mityczny rodowód"30. Bardzo ważny punkt w pisarstwie autora Xięgi bałwochwalczej stanowi, zdaniem badacza, zależność mitu od historii. Oba pojęcia są dla Schulza nierozerwalne. Dzieje tworzą się na podstawie mitu, natomiast paralelizm historii i mitu dotyczy tyleż historii publicznej, ile prywatnej. Całbecki nawiązuje w swojej rozprawie do poglądu Boleckiego: omawiając Schulzowskie rozumienie mitu, podkreśla pozaracjonalną i niezwerbalizowaną dla pisarza istotę historii.

Bachofen w dziele Das Mutterrecht (Matriarchat) twierdzi, że „początek wszelkich zdarzeń tkwi w micie” i że „Bez poznania początku wiedza historyczna nigdy nie dotrze do wewnętrznego kresu"31. Całbecki widzi zbieżność między Bachofenem a Schulzem w podejściu do koncepcji mitu. Dodaje jednak, iż do pokonania dychotomii historii: publiczna-prywatna, potrzebne ,jest [...] wkomponowanie narracji mitycznej w porządek interpretacji historycznej i uznanie jej za podstawę rozumienia dziejów zarówno w porządku prywatnym, jak i publicznym” ${ }^{32}$. Według badacza:

odwołuje się [Schulz] do kategorii mitu z tych samych powodów, na których Bachofen oparł swoja teorię. [...] a cała autobiografia zapisana w Sklepach cynamonowych to opis rywalizacji dwóch porządków uosobionych przez skonfliktowane $z$ sobą płcie ${ }^{33}$.

U Schulza, w optyce Całbeckiego, ontogeneza nakłada się na filogenezę i artysta traktuje tożsamo początki własnej egzystencji z egzystencją gatunku ludzkiego. Wyjazd ojca, o którym wspomina się w pierwszym zdaniu Sklepów cynamonowych, i brak mężczyzn w pierwszym opowiadaniu Sierpień - odnoszą się do panowania systemu matriarchalnego. U zarania dziejów nie było mężczyzn, role społeczne odgrywały jedynie matki oraz ich dzieci. Zdaniem badacza, rynek miasta porównany do biblijnej pustyni, bezproduktywnej i jałowej, stanowi wzorzec kultury patriarchalnej: „Centrum [...] jest puste, a wszystko, co istotne, odbywa się na pogańskich peryferiach"34. Tam spotykamy najpierwotniejsze bóstwa porządku ginaj-

M. C ałb e ck i, Drohobycki matriarchat. Antropologiczne wątki „Sklepów cynamonowych” Brunona Schulza. „Schulz / Forum” 2015, z. 5.

B. S c h u lz, Do Stanisława Ignacego Witkiewicza, list z 12 IV 1934. W: Dzieła zebrane, t. 5, s. 109. J. J. B a c h o f e n, Matriarchat. Studium na temat ginajkokracji świata starożytnego podtug natury religijnej i prawnej. Przeł. R. Re s z ke. Warszawa 2007, s. 12. 
kokracji. Sierpień to odpowiednik biblijnej Genesis. Zawiera on opis trzech bóstw kobiecych.

Pierwsze z nich, Adela, przedstawiona została na wzór żeńskiego bóstwa - Pomony. Schulz na samym wstępie Sklepów cynamonowych umieszcza jej opis. Bogini jako taka też okazuje się pierwszym obiektem czci religijnej w hipotezie Bachofena. Od obrazu Pomony rozpoczyna się duchowa autobiografia Schulza. Pomona wraca i jej powroty wydają się cykliczne, co jest typowe dla narracji opartej na micie. Atrybut bogini stanowią płody ziemi. „Istnienie telluryczne”, jak zauważa Całbecki, ,jest wymownym znakiem sakralizacji kobiety"35. Lato, ogród, natura, życie wegetatywne w całości podporządkowane zostają kobiecości. Niepohamowana płodność wiąże się ściśle z płodnością Demeter.

Drugim kobiecym bóstwem poddanym prawom matriarchatu jest wariatka Tłuja, „bogini wynaturzonej pogańskiej płodności” ${ }^{36}$. Tłuja reprezentuje łączność z materią i życiem biologicznym. Schulz pisze, że jest „podobna do bożka pogańskiego" i jej twarz jest pół zwierzęca, pół boska ${ }^{37}$. Zdaniem Całbeckiego, mamy tu do czynienia $z$ najpierwotniejszymi i najprymitywniejszymi formami ujawniania się świętości, typowymi dla mysterium tremendum. Widzimy tu człowieczeństwo w absolutnych, heterycznych początkach. Stan ekstazy, orgia jako rytuał religijny wiąże się z najwcześniejszymi formami kultu znanymi człowiekowi. Według Mircei Eliadego „orgia odpowiada niezróżnicowaniu sprzed aktu stworzenia”38.

Trzecie bóstwo kobiece pojawiające się w Sierpniu to ciotka Agata. Ostatnia bogini jest podstawa rytu matriarchalnego. To matka par excellence. Istota, która rodzi i wzrasta w swoich stworzeniach. Jest zobrazowana przez Schulza jako mięso białe i płodne, „bujajace [...] jakby poza granicami osoby, zaledwie luźnie utrzymywanej w skupieniu, w więzach formy indywidualnej [...]” - „Była to płodność niemal samoródcza, kobiecość pozbawiona hamulców i chorobliwie wybujała”, gotowa „rozpaść się, rozgałęzić, rozsypać w rodzinę”39. Badacz podkreśla tutaj skrajny biologizm opisu i więzy krwi. Ciotka Agata przypomina fetysz płodności paleolitu.

Poruszoną problematykę kontynuuje Całbecki w artykule „Metafizyczna misja”. Ojciec i próba statuowania patriarchalnego porzadku $w$ „Sklepach cynamonowych” Brunona Schulza ${ }^{40}$. Eksperyment $\mathrm{z}$ ptakami $\mathrm{z}$ opowiadania o tym samym tytule, zdaniem autora studium, jest próbą stworzenia świata przez mężczyznę na miarę własnej, „logocentrycznej zasady” ${ }^{41}$. Mamy zatem do czynienia z mityczna „rywalizacją starszego porządku żeńskiego z nową zasadą męską". Badacz w tym punkcie odnosi się do Ericha Fromma i jego twierdzenia, że „Zanim ustanowiono męskie

Ibidem, s. 24.

Ibidem, s. 26.

B. Schulz, Sierpień. W: Proza, s. 41.

M. Eli a d e, Sacrum, mit, historia. Wybór esejów. Wybór, wstęp M. Czerwińs ki. Przeł. A. Tat a rki ew ic z. Wyd. 4. Warszawa 2017, s. 140.

Schulz, Sierpień, s. 43.

M. C ałb e c ki, „Metafizyczna misja”. Ojciec i próba statuowania patriarchalnego porzadku w „Sklepach cynamonowych” Brunona Schulza. „Annales Universitatis Paedagogicae Cracoviensis. Studia de Cultura" 2018.

Ibidem, s. 15. 
zwierzchnictwo, występowała u mężczyzn "zazdrość o ciążę" [...]"42. Metafizyczna misja ojca opiera się na duchowej zasadzie Demiurga. Ojciec staje się „ojcem w ogóle” i główny cel patriarchalnego porządku to „oderwanie się ducha od zjawisk naturalnych". Zgodnie ze zdaniem Całbeckiego, zasada ojcowska przedstawiana jest w Sklepach cynamonowych jako podejrzana i marginalna ${ }^{43}$.

\section{Perspektywy badawcze}

\section{Demiurgos i materia (Wtóra Ksiega Rodzaju)}

Na początku opowiadania Nawiedzenie pojawia się wreszcie postać ojca. Okres, w którym działa, to zima, kiedy on „schodził do [...] zimnych i ciemnych pokojów [...] [i] szedł budzić ciężko chrapiących $z$ twardego jak kamień snu"44. Czytelnik szybko dowiaduje się, że ojciec zaczyna chorować. Następuje jego groteskowa walka z Bogiem, w której bohater ten zostaje pokonany i zanika. W końcu staje się mały jak kupka śmieci, „którą Adela co dzień wynosiła na śmietnik”45.

W Ptakach zimowe dni są opisane jako pełne nudy. Scena sprzatania stanowi pierwsze spotkanie służącej Adeli z ojcem. Ojciec ją obserwuje podczas sprzątania, a jego ciałem wstrząsa „rozkoszny spazm orgazmu” 46 . Tomasz Bocheński komentuje to tak, że bohater Schulza „odczuwa orgiastyczna przyjemność unicestwienia siebie [...]. [...] sprzątająca-śmierć sprowadza absolutna rozkosz, rozkosz unicestwienia "ja"" ${ }^{7}$. Autor Sklepów cynamonowych podkreśla nieograniczoną władzę Adeli nad ojcem. W dalszej części opowiadania widzimy, jak służąca unicestwia jego ptasie królestwo. Podobna do szalejącej menady, tańczy taniec zniszczenia i gromada ojca wznosi się w powietrze. Impreza z ptakami była ostatnim przejawem działalności ojca przed zniknięciem, później już tylko „Po całym mieszkaniu słychać było kłapanie pantofelków Adeli" 48 ...

W opowiadaniu Manekiny Schulz wprowadza czytelnika w przestrzeń, w której młode krawcowe ze skrawków materiałów szyją manekina. Jest on przedstawiony jako „cicha dama”, „pani sytuacji”, „moloch nieubłagany”, ,jak tylko kobiece molochy być potrafia $[\ldots]$... 4 . Przed tym molochem w towarzystwie Poldy i Pauliny rozwija ojciec swój „traktat o manekinach” ${ }^{50}$. Od samego początku kwestionuje on nie tylko monopol Demiurga w tworzeniu, ale również jego władzę jako taka. Demiurgos Schulza jest bardzo podobny do Demiurga gnostyków, jeżeli nawet nie tożsamy z nim. To uzurpator, lecz nie złośliwy. Niedoskonałość i cierpienie świata pochodzą z pomyłki i niedoskonałości samego Demiurga. W kolejnej części - w Trak-

Całbecki, Drohobycki matriarchat, s. 29.

C ałbecki, „Metafizyczna misja”, s. 10.

Schulz, Nawiedzenie, s. 46.

Ibidem, s. 51.

B. Schulz, Ptaki. W: Proza, s. 53.

T. B o c h eń s ki, Czarny humor w twórczości Brunona Schulza. W zb.: W ułamkach zwierciadła..., s. 224.

B. Schulz, Manekiny. W: Proza, s. 57.

Ibidem, s. 58.

S c hulz, Traktat o manekinach, albo Wtóra Księga Rodzaju, s. 63-64. 
tacie o manekinach. Ciagu dalszym - ojciec nie odnosi się już do Demiurga, tylko do materii. Następuje długa pochwała materii, która jest nieustannie żywa.

Materia leży u podstaw całego systemu Schulza. Gloryfikacja materii - albo dokładniej: materii w odwiecznej zmienności - odgrywa nadrzędną rolę w jego dziele. Gnostycy też przywiązują dużą wagę do materii, ale stanowi ona dla nich element negatywny, przeciwny duchowi pozytywnemu. U Schulza jest raczej odwrotny porządek. W centrum znajduje się materia ze swoimi nieskończonymi zmianami-przemianami. Duch jest obecny i materia go kusi do tego, żeby kreował. Wydaje się jednak prawie niepotrzebny, ponieważ materia jest niemal samostwórcza. Byty wykreowane przez ducha są krótkotrwałymi i nieszczęśliwymi maskami, które zaraz zostaną odrzucone w wyniku odwiecznej tendencji zmieniania się materii. W końcu wszakże ojciec wróci ponownie do tematu Demiurgosa, albo raczej demiurgii, czyli twórczości. Wygląda tu na to, że ojciec przekroczył granice gloryfikowania materii i poszedł dalej. Następnie pragnie odegrać rolę Demiurga. W tym punkcie narrator nie zgadza się z ojcem: „Co do nas, to byliśmy dalecy od wszelkich pokusów demiurgicznych" 51 . Terminologia gnostycka przydaje się Schulzowi zwłaszcza $z$ powodu swojej heretyckości. Samo słowo „Demiurgos” odnosi się do treści heretyckich. Pisarz jednak nie szuka transcendentnej postaci pozytywnej poza Demiurgiem. Istota rzeczy u Schulza znajduje się w materii, w przemienności materii.

Pierwsza część traktatu, która opatrzona jest podtytułem: albo Wtóra Księga Rodzaju, kończy się deklaracją ojca. Ojciec pragnie demiurgii, chce stworzyć po raz kolejny człowieka „na obraz i podobieństwo manekina”. Schulz wskazuje na pewien incydent, przewrotnie określając go jako „drobny i błahy”. W chwili kiedy ojciec wypowiada słowo „manekin”, manekin - dama z kłaków i płótna, ten kobiecy, nieubłagalny moloch, ożywia się. Adela zajmuje jej miejsce: „z wielkimi trzepoczącymi oczyma, pogłębionymi lazurem atropiny, z Poldą i Pauliną po obu bokach [...]" „podniosła brzeg sukni, wystawiła powoli stope [...]” „i wyprężyła ja [...]”, „On - herezjarcha natchniony [...]” „osunął się na kolana” ${ }^{2}$.

Pogaństwo i religia Mojżeszowa (Noc wielkiego sezonu)

W ostatnim opowiadaniu Sklepów cynamonowych - Nocy wielkiego sezonu, Panas zwraca uwagę na wyjątkowy obraz stworzenia świata. Ojciec, stylizowany na biblijnego proroka, wchodzi w rolę samego Stwórcy. Sklep staje się fantastycznym Kanaanem, w którym ojciec ,jak walczacy prorok”, „wędrował wielkimi krokami, z rękoma rozkrzyżowanymi proroczo w chmurach, i kształtował kraj uderzeniami natchnienia”53. Ojciec realizuje swoją sukienną kosmogonię, „wodospadami sukna, jak pod uderzeniem Mojżeszowej laski”, „u stóp tego Synaju, wyrosłego z gniewu ojca, gestykulował lud, złorzeczył i czcił Baala [...]”, ojciec „gromił z wysoka bałwochwalców potężnym słowem" 54 . W tym wyraźnie demiurgicznym opowiadaniu stylistyka biblijna jest bardziej widoczna niż w większości innych opowiadań Schulza. Natykamy się tu na opis zachowania ludzi, którzy:

51 Ibidem, s. 63.

52 Ibidem, s. 64-65.

53 B. Schulz, Noc wielkiego sezonu. W: Proza, s. 116-117.

54 Ibidem, s. 117. 
uciekali przed zmierzchem w cichym popłochu i naraz dosięgał ich ten trąd, i wysypywał się ciemną wysypką na czole, i tracili twarze, które odpadały wielkimi, bezkształtnymi plamami, i szli dalej już bez rysów, bez oczu, gubiąc po drodze maskę po masce, tak że zmierzch roił się od tych larw porzuconych, sypiących się za ich ucieczką ${ }^{55}$.

Natomiast na początku matriarchalnego opowiadania Sierpień znajduje się zupełnie inny opis ludzi:

Przechodnie, brodząc w złocie, mieli oczy zmrużone od żaru, jakby zalepione miodem, a podciągnięta górna warga odsłaniała im dziąsła i zęby. I wszyscy brodzący w tym dniu złotym mieli ów grymas skwaru, jak gdyby słońce nałożyło swym wyznawcom jedną i tę samą maskę - złotą maskę bractwa słonecznego; i wszyscy, którzy szli [...], pozdrawiali się w przejściu tą maską [...], szczerzyli do siebie ten grymas bakchiczny - barbarzyńską maskę kultu pogańskiego ${ }^{56}$.

W obu przypadkach mamy ewidentnie do czynienia z motywem maski. Jak jednak ogromnie się różnią od siebie sposoby wykorzystania go! W pogańsko-matriarchalnym Sierpniu każdy przechodzień nosi „barbarzyńską maskę kultu pogańskiego”, u wszystkich widać „ten grymas bakchiczny” z powodu nadmiaru żaru słońca. Ludzie pozdrawiają się i szczerzą zęby. Wspólna maska staje się cechą rozpoznawczą, znakiem przynależności do wspólnoty bakchicznej. W złotej epoce sierpniowego pogaństwa „barbarzyńska maska kultu pogańskiego” jednoczy wszystkich. Inaczej jest w biblijno-patriarchalnej Nocy wielkiego sezonu - tu uciekają oni w popłochu przed zmierzchem. Trąd dosięga ich i wysypuje się ciemnym wykwitem na czołach. Ludzie tracą twarze i uciekając gubią maskę po masce, i są „bez rysów, bez oczu". W tym drugim przypadku maska nie pokrywa twarzy, lecz sama twarz stanowi maskę. Jednolity żywioł bakchiczny staje się bezosobowym uciekającym tłumem. Nadchodzi zmierzch jesieni religii mojżeszowej. Na samym początku opowiadania autor przestrzega nas:

Każdy wie, że w szeregu zwykłych, normalnych lat rodzi niekiedy zdziwaczały czas ze swego łona lata inne, lata osobliwe, lata wyrodne, którym - jak szósty, mały palec u ręki - wyrasta kędyśs trzynasty, fałszywy miesiąc $c^{57}$.

I trochę dalej: „To, o czym tu mówić będziemy, działo się tedy w owym trzynastym, nadliczbowym i niejako fałszywym miesiącu tego roku [...]"58. Wydaje się, że dla Schulza świat patriarchalnego, biblijnego porządku nadchodzi jak zaraza na ludzi w tym 13 fałszywym miesiącu zdziwaczałego i zwyrodniałego roku.

Pod koniec opowiadania czytamy, iż „zapomniane potomstwo [...] ptasiej generacji, którą ongiś Adela rozpędziła na wszystkie strony nieba”, wraca do Mistrza. To sztuczne potomstwo jest jednak „zdegenerowane”, „zmarniałe wewnętrznie”, „wewnatrz puste i bez życia” 59 . Ptaki nie rozpoznają ojca: „Na darmo wołał nad nie dawnym zaklęciem [...]”. Klienci w sklepie zabijają nadlatujące ptaki kamieniami. Ojciec nie umie ich powstrzymać. Kiedy trafił do „miejsca rzezi, cały ten świetny ród ptasi już leżał martwy, rozciągnięty na skałach”. Wtedy dopiero ojciec obser-

Ibidem, s. 114.

Schulz, Sierpień, s. 38-39.

Schulz, Noc wielkiego sezonu, s. 111.

Ibidem, s. 112.

Ibidem, s. 119. 
wuje „całą lichotę tej zubożałej generacji, całą śmieszność jej tandetnej anatomii”"60. Demiurgia załamanego patriarchy obraca się teraz w gruzy. Prorok sam przepowiedział wcześniej, w Traktacie o manekinach (ciagu dalszym), jakby przestrzegał siebie: „Kto ośmiela się myśleć, że można igrać $\mathrm{z}$ materią, że kształtować ją można dla żartu, że żart nie wrasta w nią, nie wżera się natychmiast jak los, jak przeznaczenie?"61 Materia jednak kusi ducha tak mocno, iż nie jest on w stanie stawiać oporu stworzeniu.

\section{Mit i sacrum (Xięga bałwochwalcza)}

\section{Słowo i obraz}

„Istotą rzeczywistości jest s e n s. [...] Stare kosmogonie wyrażały to sentencją, że na początku było słowo" - pisze mitotwórca Schulz w swoim programowym tekście Mityzacja rzeczywistości. Pierwotne słowo to centralny temat całego traktatu. Jednak to pierwotne słowo, zanim zdegenerowało się $\mathrm{w}$ „potoczne dzisiejsze jego znaczenie”, było „majaczeniem krążącym dookoła sensu światła [...]”62. Poezja „przywraca słowom ich miejsce”. Pod koniec traktatu autor twierdzi, że „także obraz jest pochodna słowa pierwotnego, słowa, które jeszcze nie było znakiem, ale mitem, historią, sensem"63. Ponad rok wcześniej Schulz napisał inny tekst programowy, list do Witkiewicza:

Początki mego rysowania gubią się w mgle mitologicznej. Jeszcze nie umiałem mówić, gdy pokrywałem już wszystkie papiery i brzegi gazet gryzmołami, które wzbudzały uwagi otoczenia ${ }^{64}$.

Majaczenie i gryzmoły krążące dookoła sensu światła to jedna i ta sama rzecz. Mały Bruno rysował, zanim zaczął mówić. Na początku życia drohobyckiego mitotwórcy, tak samo jak w zaraniu istnienia naszego gatunku homo sapiens, było nie tyle słowo, na co wskazują stare kosmogonie (przynajmniej nie w znaczeniu, w którym dzisiaj rozumiemy „słowo”), ile na początku był obraz. W dalszej części listu do Witkacego pisze Schulz:

Na pytanie, czy w rysunkach moich przejawia się ten sam wątek, co w prozie, odpowiedziałbym twierdząco. Jest to ta sama rzeczywistość, tylko różne jej wycinki. [...] Rysunek zakreśla ciaśniejsze granice swym materiałem niż proza. Dlatego sądzę, że w prozie wypowiedziałem się pełniej ${ }^{65}$.

Obraz jest bliżej słowa pierwotnego, niż słowa w dzisiejszym znaczeniu. Poeta potrafi wykonać tytaniczne dzieło i przywrócić zdegenerowanemu słowu początkowy jego sens. Obraz natomiast za sprawą swoich ciasnych granic znajduje się bliżej światła, bliżej sedna rzeczy. Jeśli pragniemy pojąć istotę świata, powinniśmy cofnąc się do mitologicznych korzeni. Jeżeli chcemy wgłębić się w tajemnicę słowa Schulza, musimy wrócić do jego rysunkowych początków. W swoich grafikach

B. Schulz, Traktat o manekinach (ciag dalszy). W: Proza, s. 66.

62 B. Schulz, Mityzacja rzeczywistości. W: Proza, s. 334.

63 Ibidem, s. 335.

64 Sc hulz, Do Stanisława Ignacego Witkiewicza, s. 105.

65 Ibidem, s. 106. 
artysta wyraża uczucie ograniczenia, nie potrafi uciekać w doskonałe labirynty własnej prozy. Skromny geniusz zmuszony jest w tych rejonach docierać bezpośrednio do sedna.

\section{Mitologia i religia}

Witkacy uznaje genialność tak dzieł literackich, jak i twórczości plastycznej swojego przyjaciela ${ }^{66}$. Ficowski zaś ogranicza wielkość autora Sklepów cynamonowych tylko do prozy: ,jego [tj. Schulza], skądinąd świetne, rysunki nie dadzą się porównać $\mathrm{z}$ jego pisarstwem, $\mathrm{z}$ kreatorskim geniuszem literackim [...]"67. Jak sam autor Xięgi bałwochwalczej stwierdził, w prozie wypowiedział się pełniej. Uważał też jednak, że przez twórczość plastyczną i przez prozę przewija się taki sam wątek. Rysunki i ryciny Schulza wyrażają, moim zdaniem, dużo więcej, niż uznawano do tej pory. Jego grafiki nie zostały jeszcze wyczerpująco zanalizowane. Dosłowność i drastyczność sztuki plastycznej autora Xięgi bałwochwalczej zniechęca badaczy do pełnej interpretacji. Jak już podkreślałem wcześniej, Schulz stwierdził, że bliski mu jest antyk i „swoją kreację, fantazjowanie i snucie wywiódł z pogańskiego pojmowania życia”. Schulz-poganin nie odbiera mitologii jak zwykły współczesny profan. Dla niego mit jest pełen sakralnej aury pradawnych epok. Mitotwórca wkracza do krainy swoich mitów jak dziecko, kreator własnych światów. W słownictwie autora Sklepów cynamonowych wyrazy „mitologia” i „religia” to synonimy: „mitologia” = „religia”. W tym sensie artysta staje się kapłanem uniwersalnej prareligii mitu pierwotnego. Jeśli wrócimy do listu do Witkiewicza, możemy dostrzec, że „Artysta jest aparatem rejestrującym procesy w głębi, gdzie tworzy się wartość"68. Nie jest bluźnierczym Demiurgiem, twórca, lecz raczej odkrywcą starożytnych odwiecznych sensów. Mityzacja rzeczywistości stanowi powrót do prapoczątków. Tam dopiero rzeczywistość odnajduje swoją istotę, tam staje się faktycznie rzeczywistością. Dzieło pisarza jest zanurzone w atmosferze religijnej. Debiut artystyczny Schulza - Xięga bałwochwalcza - poprzedzający jego utwory literackie i stanowiący ukoronowanie jego sztuki rysunkowej, to dzieło sakralne. Nie ma w tym żadnej intencji związanej z groteskowością, bluźnierstwem czy prowokacją. Jest po prostu opus sacrum ściśle wyrażającym rozumienie religijności przez Schulza, manifestem jego całościowej koncepcji dzieła artystycznego i literackiego.

\section{Xięga bałwochwalcza}

Często badacze podkreślają monotematyczność Xięgi bałwochwalczej polegająca na jej charakterze masochistycznym, żeby dyskredytować to dzieło i umieścić je na nieporównywalnie niższym miejscu niż prozę autora Sklepów cynamonowych. Ficowski w artykule Feretron z pantofelkiem pisze o masochizmie Schulza: wstęp, przypisy, aneks J. Fic ow ski. Kraków 1975, s. 163-164.

67 J. F i c o w s ki, Ilustracje do własnych utworów. W: Regiony wielkiej herezji i okolice. Bruno Schulz i jego mitologia. Sejny 2002, s. 456.

68 S c hulz, Do Stanisława Ignacego Witkiewicza, s. 108. 
Baczni obserwatorzy symptomów masochizmu jakoś nie dostrzegli lub bagatelizowali pobieżna wzmianką towarzyszący mu nieodłącznie fetyszyzm [...]. Ów kult fetyszystyczny przybiera w sztuce Schulza postać kultu sakralnego $[\ldots]^{69}$.

Badacz w swoim tekście analizującym Xięgę bałwochwalcza i noszącym ten sam tytuł podkreśla:

Niewolnicze poddaństwo, którym naznaczone są tu wszystkie twarze mężczyzn [...], prowadzi do teratoidalnego zdeformowania całych ich postaci [...]. [...] przemiana dotyczy tylko postaci Wyznawców Idola, nigdy samego Bóstwa. Kobieta jest tu zawsze nietykalna, [...] upiększona, przedstawiana niekiedy z większą dbałością o jej urodę i kobiecy powab niż o plastyczną jakość rysunku czy o konsekwencję stylistyczną. Nie tylko męskie karły oddają jej cześć, lecz również sam rysunek zdaje się być czynnością obrzędową, aktem kultu. To ona, kobieta, jest arcydziełem - zdaje się sugerować Xięga. Rysunek, jego forma, maestria nie maja prawa konkurować $\mathrm{z}$ jej samowystarczalną doskonałością, powinny tylko wiernie ją utrwalić... Toteż nawet sama kreska rysunkowa służąca zarysowaniu jej kształtów staje się inna, nie konstruująca, lecz kopiująca, poddańcza i pieszczotliwa, pochlebiająca, a nie bluźniercza ${ }^{70}$.

Najbardziej trafnej analizy Xięgi batwochwalczej dokonał Bolecki, który wykazał, że klucz masochizmu nie tylko nie wyjaśnia interpretacji, ale wręcz ją deformuje. Kobieta w sztuce Schulza jest, zdaniem badaczy, bezimienna, to każda z kobiet, kobieta w ogóle. Oskarżenie o monotematyczność Xięgi bałwochwalczej możemy nawet zaakceptować. Istnieje tu właściwie jeden i ten sam wątek powtarzający się we wszystkich niemal rycinach - i takie ma być dzieło religijne, w którym nieustannie pojawia się sacrum. Wątek ten bardzo wyraźny jest na rysunku Bachanalia stworzonym przez Schulza w roku 1920, przed wykonaniem całej Xięgi bałwochwalczej. Kusząca bachantka prowadzi korowód młodzieńców, trzymając w ręce pejcz. Kobieta za nią niesie dzwoneczek, kieruje tłumem efebów pełzających za nimi w ekstatycznej rozkoszy na wzór psa, który znajduje się u stóp kobiet. $Z$ boku, nie należący do orszaku pierrot - również w uniesieniu - obserwuje bachantki. Panuje dionizyjska atmosfera unicestwienia zasady principium individuationis. Kobiety symbolizują odwieczną żywiołową przemienność materii. Korowód efebów pełzających za nimi i padających na ziemię to tłum tymczasowych i krótkotrwałych masek istnienia indywidualnego; efemeryda umierająca we wzniosłej rozkoszy w pochodzie nieustannej przemiany. Oto właśnie religia drohobyckiego pustelnika, który stoi $\mathrm{z}$ boku w stroju pierrota $\mathrm{i}$ - choć zrezygnował $\mathrm{z}$ korowodu życia - dzieli los ekstatycznej śmierci. Interpretację postaci pierrota jako wcielenia samego artysty przedstawia również badaczka Janis Augsburger ${ }^{71}$.

Swiat Schulza jest pełen zmysłowości, cielesności i erotyzmu świata pogańskiego. To w żadnym przypadku nie znaczy jednak, że atrybuty judeochrześcijańskie Xięgi bałwochwalczej, które występują np. na rycinie Procesja, wiążą się z bluźnierstwem, prowokacją czy groteską. Przeciwnie! Choć znane jest podejście kry-

J. Fi c ow s ki, Feretron z pantofelkiem. W: Regiony wielkiej herezji i okolice, s. 109, 110.

J. Fic ow ski, „Xiega batwochwalcza”. W: jw., s. 255-256.

Zob. K. Luka s, Masochizm i estetyka. O nowych kulturowo-psychoanalitycznych interpretacjach twórczości Brunona Schulza. [Recenzja książki J. A u g s b u r g e r, Masochismen. Mythologisierung als Krisen-Ästhetik bei Bruno Schulz. Wehrhahn Verlag. Hannover 2008, ss. 344]. Na stronie: https:// www.researchgate.net/publication/283238297_Masochizm_i_estetyka_O_nowych_kulturowo-psychoanalitycznych_interpretacjach_tworczosci_Brunona_Schulza (data dostępu: 10 VII 2018). 


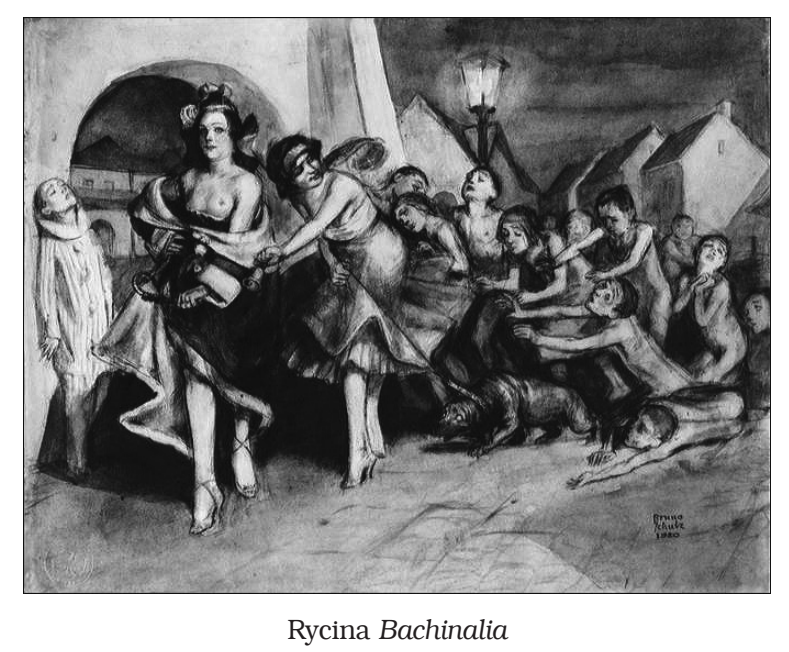

tyczne artysty do dogmatu judeochrześcijańskiego, te atrybuty, procesja religijna z feretronem przed kościołem mają za zadanie wzmacniać atmosferę sakralną. W ten sam sposób kapłan chrześcijański składa hołd ożywionemu posagowi pogańskiej bogini (Autoportret przy pulpicie rysowniczym, 1919) lub chasyd kłania się eleganckim dziewczętom na ulicy (Spotkanie, 1920). Tu również religijność wyraźnie podkreślana jest przez judeochrześcijańskie atrybuty. Artysta przekracza granice, wstępuje do różnych światów, korzysta ze wszystkich mitologii i wszystkich religii, żeby pokazać pradawny sakralny sens dziejów.

Motywy mitologiczne w Xiędze batwochwalczej nie są oparte na prostej stylizacji, są znacznie głębsze. Prześledźmy je na poszczególnych grafikach Schulza. Rycina Mademoiselle Circe i jej trupa na niektórych egzemplarzach nosi tytuł Cyrk. Imię uwodzicielki, czarownicy Circe, jak tłumaczy wielki znawca starożytnej mitologii Károly Kerényi, etymologicznie odnosi się do kręgu magicznego wokół pałacu czarownicy, gdzie jej siła uwodzicielska tworzy swój specyficzny magiczny świat ${ }^{72}$. Słowo „cyrk” z łacińskiego „circus”, „circulus” znaczy również 'krag' (w środku niego wszystko staje się tajemnicze). Circe, która zaklinała mężczyzn w świnie, jest symbolem nieustannie zmieniającej się materii.

Rycina W garderobie Unduli (albo Jej garderobiana) nosi czasem tytuł Panna Hestia. Bogini Hestia, pani ogniska domowego, stylizowana na pokojówkę, sprząta oraz wyrzuca niepotrzebne i przestarzałe formy istnienia. Adela, jak Hestia, robi porządki i ma nieograniczona władzę nad ojcem.

Na rycinie Na Cyterze widzimy boginię miłości, Afrodytę, która przybywa triumfalnie na tytułowa wyspę. Afrodyta według starogreckiego mitu pływała po morzu $\mathrm{w}$ muszli popychanej przez Zefira, bóstwo uosabiające wiatr. Zanim trafiła do Olimpu, zatrzymała się na wyspie Cyterze, pierwszym - zgodnie z legendą - miejscu kultu tej bogini. W Schulzowskiej wersji mitu muszla staje się pierwotnym symbolem wyobraźni autora, powozem. Tytuł ryciny: Na Cyterze, podkreśla, moim zdaniem, 
ruch, przemieszczanie się i tymczasowość związaną z pobytem bogini na tej wyspie. Afrodyta wysiada $z$ powozu i „Jeden [z mężczyzn] pochyla głowę, aby bogini mogła zstapić po niej na ziemię, niczym po trapie"73. Pradawna żywiołowa przemienność materii unicestwia tymczasowe jednostkowe istnienie (maska).

Ten sam wątek pojawia się na rycinie Odwieczna baśń, którą często podaje się jako wstęp Xięgi bałwochwalczej. Naga kobieta depcze siedzącego mężczyznę. Jej stopa miażdży mu twarz: „Odebranie komuś twarzy można rozumieć jako pozbawienie osobowości”74. Słowo „Undula”, imię głównej bohaterki Xięgi bałwochwalczej, jak już wspomniano wcześniej, kojarzy się z falą - strumieniem (łac. unda), to typowy symbol ruchu i przemiany.

Schulz stara się opisać gryzmoły, które krążyły wokół sensu światła, rysowanych przez niego, kiedy nie umiał jeszcze mówić:

Były to z początku same powozy z końmi. Proceder jazdy powozem wydawał mi się pełen wagi i utajonej symboliki. [...] Obraz ten należy do żelaznego kapitału mojej fantazji, jest on jakimś punktem węzłowym wielu uchodzących w głąb szeregów. Do dziś dnia nie wyczerpałem jego metafizycznej zawartości ${ }^{75}$.

Gryzmoły, majaczenie związane $z$ sensem światła, $z$ pierwotnym słowem w Schulzowskim świecie to powozy i dorożki, które symbolizują ruch oraz przemianę. Przemienność materii to centrum całego systemu artysty. „Nie ma materii martwej”, nauczał ojciec, „martwota jest jedynie pozorem, za którym ukrywają się nieznane formy życia"76. Materia staje się nieśmiertelna dzięki nieustannej przemienności. Duch, świadomość, jednostkowość są śmiertelne i tylko one umierają, wyłącznie zaś materia przemienia się. Herezja Schulza kwestionuje najbardziej podstawowe zasady patriarchatu. Taka sama rzeczywistość pojawia się w Sklepach cynamonowych. Szczegółowo o tym napisał autor w liście do Witkacego:

Substancja tamtejszej rzeczywistości jest w stanie nieustannej fermentacji, kiełkowania, utajonego życia. Nie ma przedmiotów martwych, twardych, ograniczonych. Wszystko dyfunduje poza swoje granice, trwa tylko na chwilę w pewnym kształcie, ażeby go przy pierwszej sposobności opuścić. [...] Ktoś jest człowiekiem, a ktoś karakonem, ale ten kształt nie sięga istoty, jest tylko rolą na chwilę przyjętą, tylko naskórkiem, który za chwilę zostanie zrzucony ${ }^{77}$.

\section{Ws paniałe bluźnierstwo}

\section{Twórczość-demiurgia}

Słowo „poezja” po grecku „, 'tworzyć'. Etymologicznie słowa „poeta” (

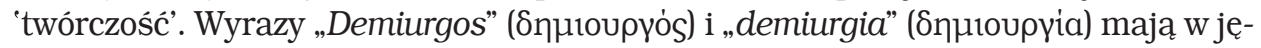

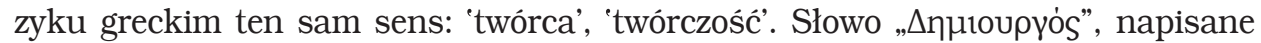
wielką literą, znaczy 'Stwórca'. W świecie Schulza „twórczość”, „demiurgia” i „poezja”

Cytera. Hasło w: Stownik schulzowski. Oprac., red. W. Bolecki, J. Jarzęb ski, S. Ro siek. Gdańsk 2006, s. 68. 
wiążą się z bluźnierczością i heretyckością. Stwórca jest bluźniercą: „Ty, Boże, wziąłeś wtedy na siebie odium herezji i wybuchnąłeś na świat tym ogromnym kolorowym i wspaniałym bluźnierstwem. O, Herezjarcho wspaniały!"78 Ojciec-Herezjarcha, pragnąc demiurgii, jest również bluźniercą, a w końcu staje się nim także sam artysta i poeta, który tworzy.

\section{Poezja-sztuka}

Sztuka i poezja jednak, zwłaszcza w Schulzowskim rozumieniu, nie są tym samym, co twórczości praktyczna, techniczna i naukowa. Poezja przywraca słowu pierwotne znaczenie i jak sam autor Xięgi bałwochwalczej twierdzi: „ten rodzaj sztuki, jaki mi leży na sercu, jest właśnie regressją, jest powrotnym dzieciństwem"79. O ile nauka i technika idą do przodu, bluźnierczo deformując świat, o tyle sztuka i poezja wracają do korzeni, rekompensując tę stratę. Schulz uświadamia sobie własna winę i grzech, ponieważ istnienie jednostkowe $z$ natury stanowi tymczasową deformację materii, dlatego też są mu przeznaczone cierpienie i śmierć. Każdy mały demiurg to uzurpator oraz grzesznik. Poeta i artysta wszakże nie deformują, lecz przeciwnie, przywracaja zgwałconej materii pierwotny jej kształt i wiernie ją utrwalają. Grzesznik staje się kapłanem. Sztuka tworzenia mitu pojawia się jako technika odkrywania pradawnej powszechnej religijności. Sacrum w tym świecie jest wszechobecne.

\section{Ekstaza-religia}

Według Michała Pawła Markowskiego „u Schulza artysta rodzi, nie płodzi [...]”. Mamy do czynienia $z$ „feminizacja procesu twórczego”. Uległy artysta składa hołd materii i natchnienie „przychodzi z zewnątrz” ${ }^{80}$, od materii do ducha. Dzieło sztuki nie jest tworem umysłu, intelektu artysty - „Artysta jest aparatem rejestrującym procesy w głębi [...]" 81 . W ekstatycznym natchnieniu przywraca światu stracony sens. „Ekstaza” (gr. '̇kotaors), znaczy 'wychodzenie $z$ siebie', negacje podmiotowości, powrót do żywiołu, stan religijny par excellence. Jest ona jedynym źródłem prawdziwego natchnienia, powrotem do korzeni świata, do pierwotnej jedności wszystkiego, do jedności z bóstwem; to może najważniejsze słowo w świecie drohobyckiego mitotwórcy, słowo kluczowe dla interpretacji jego dzieła. Stan ekstatyczny to wyłączna droga do religii pierwotnej. Każdy dogmat wiąże się z późniejszą jej deformacją i degeneracją. Krytyka religii mojżeszowej przez Schulza ogranicza się do dogmatu, a nie do religii jako takiej.

\section{Kabała i gnoza}

Sacrum w świecie autora Sklepów cynamonowych ma wartość kluczową i charakter wyłącznie ekstatyczny. W twórczości Schulza krytyka dogmatu judeochrześci-

B. Schulz, Wiosna. W: Proza, s. 153.

B. Sc hulz, Do Andrzeja Pleśniewicza, list z 4 III 1936. W: Księga listów (2016), s. 120.

M. P. M a r kow s ki, Powszechna rozwiazłość. Schulz, egzystencja, literatura. Kraków 2012, s. 38, 135.

Sc h u lz, Do Stanisława Ignacego Witkiewicza, s. 108. 
jańskiego, choć rzeczywista, w żadnym przypadku nie dotyczy wszystkich elementów tej religii. Pisarz jest, owszem, bliżej antyku, wydaje się raczej poganinem, ale poganinem nowoczesnym, tzn. po upływie tysiącleci panowania religii monoteistycznej, a zwłaszcza - po diagnozie postawionej przez Nietzschego, dotyczącej śmierci Boga w kulturze okcydentalnej. $Z$ jednej strony, motywy mitologiczne nie maja już aury religijnej tak jak kiedyś. $Z$ drugiej, dogmat monoteizmu stracił swoją potęgę i uniwersalność w świecie zachodnim. Atrybuty judeochrześcijańskie wszakże zachowały w całości charakter religijny i są wszechobecne w twórczości Schulza - tak w Xiędze bałwochwalczej, jak i w jego prozie. Nie wykazują cech parodii, ich celem jest natomiast wzmacnianie religijności i sakralności dzieła. W tym porządku można także postrzegać miejsce motywów kabalistycznych w twórczości autora Sanatorium Pod Klepsydra. Jak udowodnił Panas, znajduja się one w dziele Schulza wszędzie, szczególnie bogate są te, które dotyczą mesjanizmu, prowadząc bezpośrednio do świata sacrum. Motywy gnostyczne nie ograniczają się tylko do postaci Demiurga i błyszczą heretyckością. Kabała i gnoza wzbogacają całe dzieło, otaczając je aurą mistycyzmu.

W artykule Cienie pod czerwona skała Agata Bielik-Robson pisze, że „"ciemna siła życia" [...] umieszcza się u dołu, u prawdziwego spodu-źródła [...]" twórczości Schulza, „kabała, chasydyzm, niemiecka Lebensphilosophie” natomiast „wtórnie nakładają się na ów spód od góry"82. Dalej w tym samym artykule czytamy:

Zadaniem pisarza jest raczej przyjąc pozycję Boga, tego prawdziwego Boga, nie od prawa i porządku, lecz od kreacyjnej obfitości, któremu „nie chodziło o ścisłość”, lecz który stwarzał, mówiąc, „co mu ślina na język przyniosła" $[\ldots]^{83}$.

W świecie Schulza stworzenie może być bluźniercze i heretyckie, ale również wspaniałe. Samo kreowanie, jeśli to kreowanie natchnione, jest Boskie i prowadzi do świata poezji. Cała Demiurgia jednak po procesie tworzenia zastyga, staje się skostniała jak świat ptaków ojca. Wspaniałość aktu kreacji jest skazana na upadek i panowanie imperium nudy, a Stwórca-Herezjarcha zmienia się w smutnego Demiurga.

\section{Dyskredytacja cywilizacji}

Wspomniałem już o podejściu krytycznym Schulza do podstawowego dogmatu dotyczącego powszechnej religii świata zachodniego, religii judeochrześcijańskiej. W opowiadaniu Księga pisarz ukryty pod postacią narratora odnosi się do Biblii, nazywając świętą księgę religii mojżeszowej „,skażonym apokryfem” ${ }^{84}$. Sztuka autora Sklepów cynamonowych nie tylko nie mieści się w ścisłych granicach dogmatu, lecz przeciwstawia się w sposób radykalny najbardziej fundamentalnym wartościom patriarchalnej religii monoteizmu. $Z$ drugiej strony, artysta jest krytyczny nie tylko wobec dogmatu religii, ale także wobec filozofii, która, jego zdaniem, różni się głę- 
boko od sztuki i nie umie jej interpretować ani równać się $\mathrm{z}$ nią, będąc $\mathrm{z}$ natury powierzchowna i sztywna:

W dziele sztuki nie została jeszcze przerwana pępowina, łącząca je z całością naszej problematyki, krąży tam jeszcze krew tajemnicy, końce naczyń uchodzą w noc otaczającą i wracają stamtąd pełne ciemnego fluidu. W filozoficznej interpretacji mamy już tylko wypruty z całości problematyki preparat anatomiczny ${ }^{85}$.

W swoim artykule, zatytułowanym Schulz - dadaista? Parodystyczna krytyka kultury europejskiej $w$ opowiadaniu Brunona Schulza „Dodo” Całbecki twierdzi, że „opowiadanie Dodo jest w największym stopniu oskarżeniem całej tradycji patriarchalnej" 86 . Schulz przyjmuje stanowisko zgoła rewolucyjne i skrajne. Całbecki, badając „szczególny styl, zespół związków frazeologicznych czy leksemów, jakimi posługuje się narrator [...]"87, obserwuje, iż autor Wiosny używa dwóch różnych stylów językowych, żeby opisać głównych bohaterów opowiadania, Doda i wuja Hieronima. $Z$ analizy Całbeckiego wynika, że w oczach narratora model życia Doda stanowi realizację ideału starożytnej filozofii stoików. Egzystencja chorego młodzieńca w pełni odzwierciedla wzorzec biografii największego myśliciela antyku: „Dodo jest wcieleniem Sokratesa, czy szerzej, jego biografia urzeczywistnia model antycznego filozofa [...]"88. Badacz wnioskuje, że ironia pisarza nie została skierowana do upośledzonego chłopaka, lecz do całej tradycji filozofii starożytnej. Kiedy Schulz zaczyna charakteryzować drugiego bohatera, wuja Hieronima, „gruntownie zmienia się język opisu [...]"89. Od terminologii filozoficznej przechodzi autor do stylu biblijnego. Chorego na schizofrenię starca przedstawił artysta jako proroka, a ,jego biografia jest trawestacją losów jednego z doktorów Kościoła - świętego Hieronima ze Strydonu"90. Pisarz ukazuje Sokratesa - wzorzec filozofii antycznej, jako umysłowo upośledzonego, a proroków biblijnych jako chorych psychicznie.

Podejście krytyczne autora Sklepów cynamonowych do cywilizacji zachodniej obserwuje również Czesław Karkowski w książce Kultura $i$ krytyka inteligencji $w$ twórczości Brunona Schulza. Badacz zaczyna swoją analizę od faktu zakwestionowania przez Nietzschego „wartości współczesnego mu świata, gdzie wraz z formalizmem idzie kult wiedzy i apoteoza człowieka, który jak Sokrates zdolny jest rzekomo poznać wszystko, a w istocie ogarnia jedynie oderwane fragmenty całości" ${ }^{1}$. Karkowski cytuje fragment opowiadania Schulza Księga. Ojciec mówi tam, że „istnieja tylko książki. Księga jest mitem, w który wierzymy w młodości, ale $z$ biegiem lat przestaje się ją traktować poważnie"92. Narrator sprzeciwia się temu po-

S c hulz, Do Stanisława Ignacego Witkiewicza, s. 107.

M. Całb e cki, Schulz - dadaista? Parodystyczna krytyka kultury europejskiej $w$ opowiadaniu Brunona Schulza „Dodo”. W zb.: Schulz. Między mitem a filozofia.. Red. J. M i c hali k, P. B u r s zty k a. Gdańsk 2014, s. 218.

Ibidem, s. 219.

Ibidem, s. 221.

Ibidem, s. 222.

Ibidem, s. 223.

Cz. Karkow ski, Kultura i krytyka inteligencji $w$ twórczości Brunona Schulza. Wrocław 1979, s. 33-34.

Schulz, Księga, s. 124. 
dejściu i jest przekonany, iż Księga to postulat i zadanie. Według badacza Schulz w swojej koncepcji kultury wykazuje, że „człowiek zatracił już swe pierwotne zdolności, [...]. [...] autentyczny jest ten, kto pozostaje w zgodzie ze swą pierwotna naturą" ${ }^{93}$. Karkowski twierdzi:

autor Wiosny [za Bergsonem] wprowadza wniosek, że współcześnie działalność intelektualna zdominowała psychikę ludzką powodując powstanie wtórej rzeczywistości, noszącej znamiona intelektualnych poczynań. Ta „wtóra rzeczywistość” decyduje o racjonalnym charakterze obecnego świata rugując zeń wszystko, co ma charakter irracjonalny $[\ldots]^{94}$.

W prozie Schulza „cały śmietnik cywilizacji, wszystkie przedmioty poniżone przez intelekt, [...] stają się domeną pierwszej rzeczywistości i z tego właśnie względu godne uwagi”, „wszelki kontakt ze światem przy pomocy rozumu oraz intelektualne operacje na jego materii sa "nienaturalne»"95. Badacz podkreśla, że „Zakładana [jest] przez pisarza opozycja instynktu i intelektu, [...] bezinteresowne i autentyczne wartości kulturowe oraz wtórne, użytkowe cele cywilizacyjne" ${ }^{96}$.

Markowski w swojej książce Powszechna rozwiazłość. Schulz, egzystencja, literatura dokonuje gruntownej i całościowej analizy dzieła pisarza. Interesuje mnie tutaj koncepcja badacza dotycząca Schulzowskiej materii jako życia. W rozdziale Bio-grafia Markowski zwraca uwagę na opozycję między dzoe a bios.

Dzoe to życie niezindywidualizowane, biologiczne w sensie ścisłym, organiczne, nad którym [...] nie panujemy, [...] bios natomiast to życie wpisane w jednostkową biografię, przepuszczone przez jednostkowe filtry zahaczone w kulturze ${ }^{97}$.

Zdaniem badacza, w Schulzowskiej opozycji: forma-treść, drugie słowo stanowi synonim życia, substancji, a nawet natury - treść $=\dot{z} y c i e=$ substancja = natura. Materializm Schulza jest witalizmem i odwrotnie ${ }^{98}$. Markowski wspomina również dwa sprzeczne podejścia wobec natury według teorii Pierre’a Hadota: postawy prometejską i orfejską.

Ta opozycja między postawą prometejską a orfejską odpowiada różnicy między technologią a sztuką w naszej cywilizacji. Pierwsza doskonali narzędzia podporządkowywania natury, druga narzędziom przeciwstawia dyskurs lub obraz ${ }^{99}$.

\section{Wracając do opozycji forma-treść (materia), Markowski twierdzi:}

W nowożytnej metafizyce i estetyce relacja między materią i forma jest taka, że forma stanowi intelektualną matrycę, w która schwytana jest surowa materia. W tym sensie forma (idea) poprzedza materię, która jest wtórnym materiałem, służącym do wcielenia idei. U Schulza sytuacja się radykalnie odwraca. To materia (tu utożsamiona $z$ chaosem) poprzedza formę, która następuje po niej i jest w takim stopniu wtórna, że niewystarczająca ${ }^{100}$.

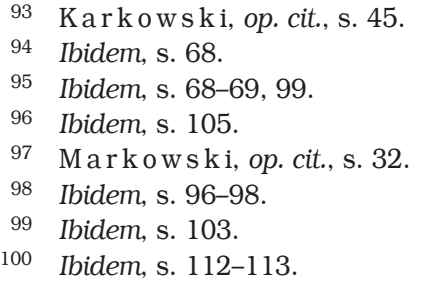


U autora Sklepów cynamonowych, zdaniem badacza, nie ma idei - w sensie neoplatońskim istniejących niezależnie od życia ${ }^{101}$ : „materia (życie) jest żywiołem z gruntu nieludzkim [...]. [...] świat form - świat ludzki - jest niedoskonały, kaleki, ułomny i nigdy nie sprosta się temu, co absolutne" ${ }^{102}$.

\section{Demiurgos versus Mesjasz}

W języku autora Xięgi bałwochwalczej i Sanatorium Pod Klepsydra słowa nie znaczą tego samego, co w tradycyjnym użyciu. Słowo Schulzowskie ma własny sens. Bałwochwalstwo dla bałwochwalcy nie jest grzechem, lecz sacrum. Słowo „herezja” może znaczyć 'ortodoksja', nie tracąc jednak również sensu klasycznego. Bluźnierstwo, jak już widzieliśmy, jest wspaniałe i patriarchat ma zdecydowanie wydźwięk negatywny. Biblia to skażony apokryf, Xięga bałwochwalcza zaś to święta księga. Ojciec zaczyna swoje eksperymentowanie $z$ ptakami, jako naukowiec i badacz, a narrator deklaruje: „Dopiero w późniejszej fazie wzięła sprawa ten niesamowity, zaplątany, głęboko grzeszny i przeciwny naturze obrót, którego lepiej nie wywlekać na światło dzienne” ${ }^{103}$. Głęboki grzech buntuje się względem natury, nie Demiurga. Owszem, Jakub jest uzurpatorem i sprzeciwia się Demiurgowi, lecz tylko po to, żeby go naśladować.

Sklepy cynamonowe i przygody Jakuba stanowią debiut literacki Schulza, a Wiosna i przygody syna Józefa to jego magnus opus, niezależnie od faktu, że sam autor nie cenił jej zbytnio. Chodzi o dzieło wyjątkowe, w którym nie tylko styl, ale i cała fabuła się zmieniają. Schulz w Wiośnie wprowadza zupełnie nowych bohaterów w stosunku do swoich wcześniejszych i późniejszych opowiadań. Jedynie narrator jest postacią wspólną, lecz nawet on w Sklepach cynamonowych to mały, bezimienny synek. Dopiero w Sanatorium Pod Klepsydra zostaje nazwany Józefem. W debiucie literackim Schulza obserwatorem zdarzeń jest narrator, ojciec zaś stanowi dla małego synka postać dwuznaczną: $z$ jednej strony, jest natchnionym herezjarchą, a z drugiej - niezrozumiałym wariatem. Ojciec przebywa w zamkniętych, sztucznych pomieszczeniach podobnych do laboratorium. Działanie Jakuba przywodzi na myśl postęp nauki oraz techniki cywilizacji i jest świadome. Historia i działanie Józefa w Wiośnie mają zgoła inny charakter. On nie naśladuje Demiurga, nie pragnie demiurgii - chce obalić jego władzę, żeby panowała kobieta. Działania Józefa to ekstatyczny, intuicyjny powrót do korzeni, maja one charakter mesjański, ale co ciekawe, mesjasz przegrywa. Nie udaje mu się obalić imperium nudy.

W analogiczny sposób do bohaterów płci męskiej - bohaterki Schulza również radykalnie różnią się między sobą. Centralną pozycję w dziele autora Sklepów cynamonowych zajmuje arcywróg głównego protagonisty Jakuba - Adela. Jest ona siostrą bliźniaczką Unduli, pierwszoplanowej postaci Xięgi bałwochwalczej. Tak samo jak Undula, Adela nie jest konkretnym człowiekiem, lecz żywiołem. Nie jest członkiem rodziny, nie jest matką ani córką, nie ma męża ani partnera, ani w ogó- 
le rodziny. Chociaż jest niby tylko sprzątaczką, rządzi w domu patriarchy. Panuje nad ojcem w sposób absolutny i stanowi przedmiot pożądania niemal wszystkich męskich postaci, które pojawiają się w prozie Schulza. To ucieleśnienie władzy i pożądania równocześnie. Taki demon wszechobecny i niedotykalny jest zarazem symbolem cielesności i zmysłowości. Matka, z drugiej strony, to postać ledwie istniejąca. Nie ma ona nad ojcem żadnej władzy. Przypomina raczej cień lub fantazmat. Wygląda na to, że jest tylko po to, żeby stanowić równowagę między ojcem a Adelą i że sam twórca wolałby ją po prostu skreślić. Warto tutaj wspomnieć, iż $\mathrm{w}$ Wywiadzie drastycznym. (Rozmowa $z$ Brunonem Schulzem) przeprowadzonym z autorem przez Józefa Nachta pisarz przyznał się:

Już we wcześniejszej młodości złapałem siebie na strasznych myślach, że chciałbym, aby matka umarła i abym miał macochę. I mówiłem sobie: Boże! Jak to możliwe pragnąć czegoś podobnego, ale nie potrafiłem myśli tych odeprzeć104.

O wiele bardziej typową matką jest ciotka Agata z opowiadania Sierpień. Agata to matka par excellence, symbol niepohamowanej płodności. Adela, główna bohaterka i centralna postać kobieca Schulza, nie ma absolutnie nic wspólnego z macierzyństwem, jest nawet wyraźnie antymatką. Ta demoniczna sprzątaczka różni się również radykalnie od kolejnej bohaterki, symbolu seksualności bez granic Tłuji. Adela jest niedotykalna i w przeciwieństwie do Tłuji - obdarzona nieskazitelną uroda. Postać kobiety jest mało realna, poza granicami principium individuationis. Nic dziwnego więc, że tak łatwo zajmuje miejsce manekina - żeńskiego „molocha”, żeby Jakub mógł złożyć jej hołd, powtarzając w ten sposób najbardziej typową scenę z Xięgi bałwochwalczej. Główna bohaterka Wiosny to, inaczej niż Adela, człowiek z krwi i kości. Bianka jest piękna, niemal nieskazitelna, narrator przywołuje „tylko jeden szczegół nic nie znaczący" (co u autora Traktatu o manekinach rozumieć należy jako szczegół wiele znaczący): ,jej spierzchłą skórę na kolanach, jak u chłopca [...]" ${ }^{105}$. Atrybuty męskie odnoszą się, moim zdaniem, do principium individuationis. W dalszym ciagu opowiadania Wiosna autor pisze też o Biance: „Z bliska widziana, jej piękność jak gdyby miarkuje się, wchodzi w siebie [...]”. Kobieca żywiołowość jednak u Schulza wyrasta poza siebie: „nosek jej nie jest wcale tak szlachetnie skrojony, a cera daleka od idealnej doskonałości. Obserwuję to z pewną ulgą [...]" ${ }^{106}$. Może słuszna okazuje się interpretacja Markowskiego, mówiąca o tym, że narrator czuje ulgę, ponieważ skazitelność prowadzi do dostępności ${ }^{107}$. W dodatku Bianka ucieka z profanem. W zasadzie wcale nie przypomina żywiołowej Adeli.

W świecie pisarza wszystkie próby demiurgiczne ojca w Sklepach cynamonowych i mesjańskie syna w Wiośnie kończą się niepowodzeniem. Markowski twierdzi, że u Schulza „to nie Mesjasz nie może przyjść, lecz rzeczywistość nie może się w pełni urzeczywistnić" 108 . W całym mrocznym dziele autora Xięgi bałwochwalczej jest tylko jeden moment, kiedy niespodziewanie dzieje się to, co wydaje się nieprawdo-

J. N a c ht, Wywiad drastyczny. (Rozmowa z Brunonem Schulzem). „Nasza Opinia” 1937, nr 77, s. 5 .

105 Schulz, Wiosna, s. 160.

106 Ibidem, s. 193.

107 Markowski, op. cit., s. 94.

108 Ibidem, s. 124. 
podobne. To wielka i wspaniała historia, która nie mieści się w zdarzeniu i tylko próbuje zaistnieć, staje się rzeczywista i Mesjasz zstępuje na ziemię! Chodzi, oczywiście, o Genialna epokę. Zdaniem Panasa, historia przyjścia Mesjasza została tu opowiedziana w pełni, a Markowski stwierdził, że małomiasteczkowy złodziejaszek Szloma to jedyny Mesjasz u Schulza ${ }^{109}$. Szlomę wypuszczono z więzienia „w same święta Wielkanocne” „wyświeżonego i odmłodzonego”:

Gdy Szloma zamknął za sobą drzwi fryzjerni, weszło w nie natychmiast niebo [...]. [...] znalazł się całkiem samotny na brzegu wielkiej, pustej muszli placu, przez którą przepływał błękit nieba bez słońca. [...]

Dzień przyjmował go wówczas w siebie umytego z grzechów, odnowionego, pojednanego ze światem, otwierał przed nim $z$ westchnieniem czyste kręgi swych horyzontów, uwieńczone cichą pięknością ${ }^{110}$

Wielka barokowa fasada kościoła Świętej Trójcy była „jak zlatująca z nieba ogromna koszula Boga [...]”. Szloma kichnął i „Bóg dawał znać przez wstrząs jego nozdrzy, że wiosna nastała. Był to znak pewniejszy niż przylot bocianów [...]”. Józef zaczął z nim rozmawiać: ,jak pusty jest dziś świat”, zauważył złodziejaszek ${ }^{111}$ i Józef odpowiedział -

Moglibyśmy podzielić go i nazwać na nowo - taki leży otwarty, bezbronny i niczyj. - W taki dzień podchodzi Mesjasz [...]. [...] sam nie [wie], co czyni [...]. [...] a ludzie obudzą się [...] i nie będą nic pamiętali. Cała historia będzie jak wymazana i będzie jak za prawieków, nim zaczęły się dzieje ${ }^{112}$.

Józef zaprosił go do środka, żeby mu pokazał swoje rysunki. Jednak Szloma:

stał zatopiony w medytacji z pantofelkiem Adeli w ręku i przyglądał mu się z głęboką powagą.

- Tego Bóg nie powiedział - rzekł - [...]. Czym zasłonisz się, co im przeciwstawisz, gdy sam już jesteś przekupiony, przegłosowany i zdradzony przez najwierniejszych sprzymierzeńców? Sześć dni stworzenia było bożych i jasnych. Ale siódmego dnia uczuł On obcy wątek pod rękami i, przerażony, odjął ręce od świata, choć jego zapał twórcy obliczony był na wiele jeszcze dni i nocy. O, Józefie, strzeż się siódmego dnia $[\ldots]$.

- Czy rozumiesz potworny cynizm tego symbolu na nodze kobiety [...]? Jakże mógłbym cię pozostawić pod władzą tego symbolu! Broń Boże, bym to miał uczynić... ${ }^{113}$

Szloma ukradł pantofelki Adeli i zniknął ${ }^{114}$. Jedna z rycin Xieggi bałwochwalczej zatytułowana Procesja ukazuje procesję religijną przed kościołem, na której czele idzie naga kobieta w czarnych pończochach i prunelkach. Wierni niosa feretron z damskim pantofelkiem. Zdaniem Ficowskiego, produkt „Siódmego Dnia” to fetysz ${ }^{115}$. Niektórzy badacze opisują Szloma jako fetyszystę. Nie Szloma nim jest, tylko Schulz. Mesjasz zszedł na ziemię, aby pozbawić świat „obcego wątku”, który siódmego dnia zatrzymał akt stworzenia ${ }^{116}$. Przybycie Mesjasza-Pomazańca urzeczywistniło się i cała historia została skasowana. Wraz z unicestwieniem fetysza 
Pomazaniec odebrał wszystkiemu sens i nastąpił koniec eschatologiczny. Powieść Mesjasz miała być dziełem życia Schulza i artysta napisał to dzieło, nie jest to jednak powieść, tylko krótkie opowiadanie. Autor wyraził tu już wszystko, to „cały, choć lapidarny, tekst”, jak stwierdził Panas. Później Schulz zdecydował się na stworzenie alternatywy dla Mesjasza i w ten sposób powstała Wiosna, najdłuższe opowiadanie i arcydzieło artysty.

Po Wiośnie Schulz napisał również Kometę, swoje requiem. Nastała wiosna i wszyscy bohaterowie wyszli na scenę, jak w przedstawieniach teatralnych pod koniec spektaklu. Szloma kicha, wariatka Tłuja tańczy, podrzucając wysoko spódnicę, a Adela wyczytuje sens z szarej monotonii dnia. Ojciec deklaruje: „Materia [...]. Panta rhei! [...]. Principium individuationis furda [...]"117, czyli w materii wszystko się zmienia, istnienie jednostkowe nie ma znaczenia i zapobiega katastrofie świata nudy. Narrator podkreśla:

Nie człowiek włamywał się tu w laboratorium natury, ale natura wciaga go w swoje machinacje [...].

Człowiek według tej teorii był tylko stacją przejściową [...]. Wszystkie wynalazki, którymi triumfował, były pułapkami $[\ldots]^{118}$.

Jeden $\mathrm{z}$ ostatnich utworów Schulza stanowi tekst krytyczny, zatytułowany Zofia Natkowska na tle swej nowej powieści - powstał on w 1939 roku. W tym eseju znajdujemy komentarze pasujące lepiej może do dzieła samego Schulza niż Nałkowskiej:

W tych ekstatycznych momentach gubi się dla autorki „principium individuationis”, znika różnica między cierpieniem a rozkoszą [...].

Wyłania się znów podstawowa teza Nałkowskiej o pochłanianiu się bytu, o samozniszczeniu. Dla jej twórczości obrazem podstawowym jest feniks płomienny, wzlatujący wyłonionym światem, ażeby się spopielić we własnym ogniu. Ten moment ekstazy zniszczenia jest $\mathrm{z}$ punktu widzenia mechaniki psychicznej usprawiedliwieniem i celem całego trudu twórczego ${ }^{119}$.

\section{Abstract \\ SOTIRIOS KARAGEORGOS University of Warsaw \\ RELIGIOUS MOTIVES IN BRUNO SCHULZ'S LITERARY CREATIVITY STATE OF THE ART AND RESEARCH PERSPECTIVES}

The article analyses the individual research views on the religious themes in Bruno Schulz's literary output formulated by Artur Jocz, Kris Van Heuckelom, Marcin Całbecki, Władysław Panas, Włodzimierz Bolecki or Jerzy Jarzębski. The last of the scholars claims that Schulz was "a believer without religion." Studies in the issue in question have numerous aspects. The present paper discusses e.g. gnostic motives (due to their heretical implications), idolatry (in the cycle of prints Xiega bałwochwalcza 〈Book of Idolatry), matriarchal hierophanies (the short story Sierpień 〈August〉), as well as such interpretive perspectives as Nietzschean Dionysity or Lurianic Kabbalah.

The paper also attempts to answer the questions about the meaning of mythisation, demiurge or creativity in Schulz's world and who his Messiah is.

118 Ibidem, s. 315.

119 S c hulz, Zofia Nałkowska na tle swej nowej powieści, s. 376, 384. 